\title{
Relationship between Level of Guidance Services and Students' Indiscipline in Public Secondary Schools in North Senatorial District of Delta State
}

\author{
William Akporobaroh Oduh', James Odunayo Agboola', Sandra Amaka Amufa ${ }^{2}$ \\ ${ }^{1}$ Department of Education, Benson Idahosa University, Benin City, Nigeria \\ ${ }^{2}$ Delta State College of Education, Sapele, Nigeria \\ Email:willoduh@yahoo.com, agboolajames20@yahoo.com
}

How to cite this paper: Oduh, W. A., Agboola, J. O., \& Amufa, S. A. (2020). Relationship between Level of Guidance Services and Students' Indiscipline in Public Secondary Schools in North Senatorial District of Delta State. Open Journal of Social Sciences, 8, 303-317. https://doi.org/10.4236/jss.2020.87024

Received: January 13, 2020

Accepted: July 25, 2020

Published: July 28, 2020

Copyright (๑) 2020 by author(s) and Scientific Research Publishing Inc. This work is licensed under the Creative Commons Attribution International License (CC BY 4.0).

http://creativecommons.org/licenses/by/4.0/ (c) (i) Open Access

\begin{abstract}
The study investigated the relationship between level of guidance services and students' indiscipline in public secondary schools in North Senatorial District of Delta State. Specifically, the study investigated the level of guidance services available to students and the level of indiscipline exhibited by students in public secondary schools. The design of the study was a correlation research design and the population of the study comprised of 166 public secondary schools with 97,316 students in North Senatorial District of Delta State. A total of 430 public secondary school students drawn from nine public senior secondary schools in North Senatorial District of Delta State were used as the sample for the study. This was selected using a simple random sampling technique. The research instrument used for this study was a questionnaire. The data collected were analyzed using the descriptive statistics of mean, standard deviation, percentage and the Pearson product Moment Correlation statistics. Findings revealed that majority of the students agreed that guidance services were available to them in public secondary schools; majority of the respondents agreed that there were high incidences of indiscipline in public secondary schools in the North Senatorial District of Delta State; there was significant relationship between guidance services and the levels of students' indiscipline in public secondary schools in the North Senatorial District of Delta State. Based on the findings, it was recommended that principals and other school administrators in public secondary schools should put in place guidance services and provide an office where privacy is made a priority. This would encourage more students to visit the office; Counsellors should be well trained on how to carry out their duties by being sent to attend many seminars and workshops
\end{abstract}


to improve on their skills.

\section{Keywords}

Guidance, Guidance Services, Students and Indiscipline

\section{Background to the Study}

Discipline is a rudimentary ingredient that plays a crucial role in the school system as it helps in upholding the moral values expected of students. It is intended to suppress, control and redirect students' behaviour. In a school system, all students must be aware of the rules/regulations before disciplinary action can be administered (Franken, 2017). Discipline in school could be explained as exercise of will-power by school authorities to enforce institutional rules and regulations already in place in order to attain expected standard behavior by students. Discipline could also be seen as acting within the norms of the society that prescribe them. In the case of the school, rules and regulations are put in place to guide learners' activities within and outside the school environment in order for them to develop intellectually, emotionally, physically, morally and socially with a view to helping them acquire education in the normative rather than in the prescriptive sense.

A cursory look at the public school environment clearly reveals that anti-social behaviours usually referred to as indiscipline pervade students' activities in secondary schools. Indiscipline has become a hydra-headed monster that has come to destroy social and academic foundations of public secondary schools. It is a phenomenon which has masqueraded in multifarious dimensions such as secret cult activities, examination malpractice, prostitution, drug abuse, rape, non-attendance of classes, assaulting teachers and social immorality. This unpleasant state of education was recognised by the Federal Government of Nigeria when it stated in the National Policy on Education, thus:

In view of the apparent ignorance of many young people about career prospects and in view of personality maladjustment among school children, career officers and counsellors shall be appointed in post-primary institutions. Since qualified personnel in this category are scarce, government shall contribute to make provisions for the training of interested teachers in guidance and counselling. Guidance and counselling shall also feature in teacher education programmes (FRN, 2004: p. 47).

The matching of indiscipline and guidance helps to determine the value of guidance and counselling to students in secondary schools. Denga (2012: p. 5) sees guidance as "a cluster of formalised educational services designed by the school to assist students to achieve self-knowledge or self-understanding which is necessary for them to attain full self-development and self-realization of their 
potential". The counsellees could only be reached through the various services rendered by guidance. Erford (2011) identified guidance services as students' appraisal service which involves the use of tests and non-test instruments to collect, analyze and interpret data on students in order to understand them better. Secondly, there is information service which is tailored towards equipping students with the necessary information in the areas of educational, vocational and personal social counselling. Counselling constitutes the third service which is a face to face interaction between the counsellor and the students, through which students are assisted towards overcoming obstacles to their academic, vocational, personal/social progress and other life needs. The fourth service is placement, which is concerned with assisting students to adjust to the next stage of development, whether in school or on the job. Orientation service constitutes another service. It is designed to familiarize fresh students with their environment. The sixth service is referral which affords the school counsellor an opportunity to refer cases which he/she cannot handle to specialists like clinical psychologist, medical practitioner and others. The seventh service is follow-up and evaluation which is designed to ascertain the extent to which the guidance activities previously carried out by the school is meeting the objectives for which the guidance programme was established and also to monitor the progress of clients in their various endeavours. Finally, is the research service which helps the school counsellor to discover relevant information that can improve students' learning and understanding. The main objective of guidance is to help the student learn to deal more effectively with himself and the reality of his environment with a view to maintaining self-discipline which is the essence of guidance in secondary schools.

Arising from the above therefore, great effort has been made by government through the Ministry of Education to offer guidance services in schools, yet, cases of indiscipline in public secondary schools are reported on a regular basis. The aim of this research, therefore, is to explore the influence of guidance services on the level of students' indiscipline in public secondary schools in the North Senatorial District of Delta State.

\subsection{Theoretical Framework}

This study is based on Social Learning Theory which was propounded by Bandura (1977). Social Learning Theory is also referred to as observational, modelling or vicarious learning where behaviour of a group or an individual acts as a stimulus for similar thoughts, actions and behaviour on the part of the observer (Omulema, 2011). This theory aimed at explaining the factors that may influence students' indiscipline in schools which include learning through observation, vicariously, imitating and identifying with wrong people whom they consider as models. Franzoi (2010) further described social models as people children are most likely to pay attention to and model or imitate their behaviour because they have social control over them. This theory can be applied in guidance 
and counselling where the counsellors and peer counsellors model actual behaviour of honesty, compassion and respect to counter the wrong behaviours that these young people may have acquired. Such models are aware of their power of being worthy to be emulated. Guidance and counselling can further use symbolic models by inviting successful models to the school to talk about their experiences while at the same time the mass media can be used to disseminate useful information from models who cannot be physically reached. School administrators can also enhance behaviour change through modelling of good behaviour. Visible and supportive administrators interact with their students even in school social activities thereby serving as a platform know the students personally.

In addition, since no individual is an island, the researchers reviewed some empirical studies carried are related to the present study. For instance, a study was conducted in Tanzania by Eliamani, Richard, \& Baguma (2013) on "Access to guidance services and its influence on students' school life and indiscipline". Descriptive correlation designs with both qualitative and quantitative approaches were used. The scope of the study was private secondary school students in Same, Tanzania. Four research questions and three hypotheses guided the study. The population for the study was 247 students while the sample size was 152 student respondents. Instruments for data collection were questionnaire and interview. Mean and standard deviation were used to analyze the data while Pearson product moment correlation was used to test the hypotheses at 0.05 level of significance. The findings revealed that accessing guidance and counselling services had an impact on students' school life as well as curbing the rates of students' level of indiscipline. The study is related to the present study because it examined access to guidance services by students which was considered in the present research.

On their own part, Onyango, Aloka, \& Raburu (2018) carried out a study on the effectiveness of guidance and counselling in the management of student indiscipline in Public Secondary Schools in Kenya. The study was informed by assertive discipline model. Mixed method approach with concurrent triangulation design was used for the study. The population of the study was composed of 431 teachers, 40 Heads of Guidance and Counselling and 40 Deputy Principals. Stratified random sampling technique was used to select teachers, deputy principals and heads of guidance and counseling. Krejcie \& Morgan (1970) sample size determination table was used in the study to determine a sample size of 28 deputy principals, 28 heads of guidance and counseling and 196 teachers. Data were collected using questionnaire, interview schedules and document analysis guides. Reliability was ascertained through split half method, and a reliability coefficient of 0.871 was realized. In order to ensure face validity of the instruments, the researcher sought expert judgment from university lecturers. Descriptive statistics and correlational analysis were used to analyze quantitative data while qualitative data was analyzed using thematic framework. The study established that there was a correlation coefficient of $r=0.503$ between guidance and counselling 
and the management of student behaviour. The findings of the current study may help the Ministry of education in the formulation of policies relevant to the management of students' behaviour in secondary schools.

Wambui (2015) conducted a study on the effectiveness of guidance and counseling services in Secondary Schools in Kenya: A Case Study of Githunguri SubCounty in Kiambu County. This study was conducted in Githunguri sub-county, Kiambu County. The sub-County had a total of 30 public secondary schools which formed the target population. In addition, all the 147 teachers in the Guidance and Counselling Departments in the schools were included in the study. From the population, the study sampled 15 schools and thus the total sample size yielded a total of 555 respondents. Quantitative data were obtained from the respondents using closed-ended questionnaire while secondary data were collected from observation and other available records. The results showed that there was an unequal representation among teacher counsellors with a greater majority being females. In addition, the teachers indicated that the time allotted for guidance and counselling sessions was too short and inappropriate as the sessions were scheduled for lunch break or at the end of lessons after school at $4.00 \mathrm{pm}$. Moreover, the guidance and counselling sessions were not frequent since in most schools, the sessions were held when the need arose. The findings further indicated that only a few students sought counselling. In general, the teachers appeared skeptical as to whether students' issues were resolved through guidance and counselling. This was attributed to several factors, the main being heavy workload by both teachers and students which could have made it difficult to accomplish effective guidance and counselling. Based on the findings, the study recommended that more time should be alloted for counselling of students.

Similarly, Salgong, Ngumi, \& Chege (2016) carried out a study on the role of guidance and counselling in enhancing students' discipline in secondary schools in Koibatek District. The purpose of the study was to examine the role of guidance and counselling in enhancing student discipline in secondary schools in Koibatek District. The study was guided by Adler \& Adler (1998) theory of personality, and humanistic theory of Albert Bandura (1995). The study adopted a descriptive survey research design. Population of study was 2624 students in 23 schools, 23 principals, 23 school counsellors and 227 teachers. A purposive sampling technique was used to select 8 schools, 8 principals and 8 school counsellors. Simple random and stratified sampling techniques were used to select 24 teachers and 262 students. The instruments used to collect data for the study were questionnaire and interview schedule. The study reliability coefficient of 0.81 was obtained. The data were analyzed using descriptive statistics such as frequency, percentage, mean scores, summary tables, and Statistical Package for Social Science (SPSS) program version 16. Findings indicated that teachers employed dynamic interactions of a group of students approach. Further, computer facilities were inadequate in guidance and counseling. From the findings, guidance and counseling had improved discipline and academic performance. 


\subsection{Statement of the Problem}

In spite of the implementation of guidance services in public secondary schools, issues of indiscipline still exist. It is common to hear parents, teachers and church leaders blame each other, for failing to teach young people to be well behaved at home, in school and in the society. Many parents have abandoned the teaching and guidance of their children which they have entrusted to the teachers alone to perform. In spite of the fact that it is stipulated in the National Policy on Education that secondary schools in Nigeria should have trained counsellors, they are usually not available in most public secondary culminating in non-availability of guidance services in schools. It is not surprising, therefore, that cases of indiscipline persist in schools. This non-availability of guidance and counselling in most public secondary school has predisposed many of the students to decadent behaviours such as indulging in drug abuse, examination malpractice, truancy, secret cults and illicit sexual behaviour. These observations have raised serious concerns on how discipline can be restored in public secondary schools. Even in schools that have functional guidance services, indiscipline has not been fully curbed. It has become imperative to investigate the level of guidance services in schools and their influence on indiscipline in public secondary schools in the area of study. The thrust of this study, stated in a question form is, could the level of available guidance services influence students' indiscipline in public secondary schools?

\subsection{Purpose of the Study}

The purpose of this study was to investigate the influence of level of guidance services on students' indiscipline in public secondary school in the North Senatorial District of Delta State. Specifically, the study sought to:

1) Determine the level of guidance services available to students in public secondary schools; and

2) Find out the level of indiscipline exhibited by students in public secondary schools.

\subsection{Research Questions}

The following research questions guided the study.

1) What is the level of guidance services available to students in public secondary schools in the North Senatorial District of Delta State?

2) What is the level of students' indiscipline in public secondary schools in the North Senatorial District of Delta State?

\subsection{Hypothesis}

The following null hypothesis was formulated and tested at 0.05 level of significance.

There is no significant relationship between the level of guidance services available and students' indiscipline in public secondary schools in the North Se- 
natorial District of Delta State.

\subsection{Significance of the Study}

This study would be of immense significance to educational stakeholders, school administrators, teachers, counsellors, students and the government. The findings of this research would highlight to educational stakeholders the importance of guidance and counselling in reducing indiscipline among public secondary schools students.

To the educational stakeholders, the findings of this study will highlight the necessities of employing guidance and counsellors to guide students, especially in checkmating them in their attitude towards their academics and every other aspect of life so to enable the students achieve their maximum potentials. To the school administrators, the finding would make them appreciate guidance services in the schools and allow the counsellors to concentrate on providing these services to students in order stem the tide of growing acts of in indiscipline in schools. The teachers would find the outcome of this research useful as it would make them to appreciate the importance of guidance services in schools as this would help them achieve their aims and objectives of their teachings. Also, the results of the study would help school counsellors to be proactive in the discharge of their counselling duties by engaging in activities that prevent negative incidences rather than being curative. The students would equally benefit from the outcome of this study as they would understand the dangers lying with acts of indiscipline and deviate from the acts and consequently, this would help them achieve their life goals and finally, the findings of the study would inform the government's decision on a mandatory employment of guidance counsellors in every level of education in Nigeria to help redirect the students attitude towards themselves and others as this would translate to a better and friendly society.

\subsection{Scope of the Study}

This study was conducted using public secondary schools in the North Senatorial District of Delta State. The variables the study covered were guidance services and the level of indiscipline (smoking of cigarette, sexual harassment, drinking alcohol, taking cocaine, marijuana, heroin, bullying fellow students, destruction of school properties, noise making).

\section{Methodology}

\subsection{Research Design}

The study adopted a correlational research design. This design was considered appropriate for this study because the researchers did not manipulate independent variables. Instead, the relationship between the independent variable and the dependent variable was to be determined. The design was also considered appropriate for the study since it lent itself to the use of questionnaire for data collection. 


\subsection{Population of the Study}

The population of the study consisted of all the students in public secondary schools in the North Senatorial District of Delta State. According to statistics obtained from the Delta State Ministry of Basic and Secondary Education which showed the statistical data of secondary schools for 2011/2012 session, Delta State had a total number of 452 public secondary schools spread across the 25 local government areas of the State. Of this figure, the North Senatorial District of Delta State has a total number of 166 public secondary schools spread across the 9 local government areas that make up the district. Thus, the total population of the study covered all the 97,316 public secondary students of the 166 public secondary schools in the North Senatorial District of Delta State from where the sample size was drawn.

\subsection{Sample and Sampling Technique}

From the population of 166 public secondary schools in the North Senatorial District of Delta State, the sample size was determined using stratified random sampling technique to sample 1 public secondary school each from the 9 local government areas in the North Senatorial District of Delta State to make a total of 9 public secondary schools. In other words, total number of nine (09) schools in the North Senatorial District of Delta State comprising of 4500 students were selected and approximately ten percent (10\%) of the total number of the students, which is 448 were selected (see Table 1). This $10 \%$ of the total students from each of the above sampled public secondary schools were chosen using simple random sampling technique. Therefore, a total of 448 students formed the sample size of the study.

Table 1. Sampling of selected schools in delta north senatorial district of delta state.

\begin{tabular}{|c|c|c|c|}
\hline $\mathrm{S} / \mathrm{N}$ & Names of Schools in Delta North Senatorial District & Students & Sample (10\%) \\
\hline 1 & Olona Mixed Secondary School, Onicha, Olona, Aniocha North & 430 & 43 \\
\hline 2 & Ubulu-Uno Mixed Secondary School, Ubulu-uno, Aniocha South & 610 & 61 \\
\hline 3 & Owanta Secondary School, Owanta, Ika North-East & 537 & 54 \\
\hline 4 & Ogbemudei Secondary School, Ika South-east & 438 & 44 \\
\hline 5 & Ashaka Mixed Secondary School, Ashaka, Ndokwa East & 418 & 40 \\
\hline 6 & Ugiliami Mixed Secondary School, Ndokwa West & 502 & 50 \\
\hline 7 & Ibusa Mixed Secondary School, Ibusa, Oshimili North & 481 & 48 \\
\hline 8 & Osadenis Mixed Secondary School, Asaba, Oshimili South & 651 & 65 \\
\hline 9 & Umutu Mixed Secondary School, Ukwuani & 433 & 43 \\
\hline & Total & 4500 & 448 \\
\hline
\end{tabular}




\subsection{Research Instrument}

The research instrument developed by the researchers was used for data collection. This was a questionnaire titled "Level of Students' Indiscipline Questionnaire" (LSIQ). The instrument was designed to elicit information as regards the objectives of the study; a rough listing of the questions was constructed initially before the final draft; the items or questions were rephrased in a way to generate the right responses; then the response format was developed; the items in the questionnaire were organized into an appropriate sequence and finally the questionnaire was formatted with clear instructions to the respondents. The instrument consisted of four sections (A-D). Section A contained the demographic data of subjects; sections $B$ and $C$ contained items that addressed each of the two research questions raised in this study. These items required the respondents to choose an option from alternatives provided as well as statements where the respondents were expected to tick on a six-point Likert response format to indicate their degree of agreement or disagreement. They were to react to the items by ticking any of Very often $(\mathrm{VO}=6)$; Often $(\mathrm{OF}=5)$; Occasionally $(\mathrm{OC}=4)$; Rarely $(\mathrm{RA}=3)$; Not at all $(\mathrm{NA}=2)$; Not sure $(\mathrm{NS}=1)$. Prior to administration of the instrument on respondents, a letter of introduction of the research questionnaire was given to the respondents to enable them understand the purpose of the instrument and what was expected of them in order to achieve the aim of the study.

\subsection{Validity of the Instrument}

The research instrument was subjected to face and content validity by three experts, two from measurement and evaluation and one from guidance and counselling all from Benson Idahosa University. The expert from Measure and Evaluation is a $\mathrm{PhD}$ holder in the field and an Associate Profession with about 22 years of research experiences. The other two from Guidance and Counselling are $\mathrm{PhD}$ holders in that field; one is an Associate Professor with 23 years of research experience while the other one is a renowned researcher of about 21 research experience. Their observations, comments and suggestions were accommodated in the final instrument because they were very constructive and meaningful to the study. Consequently, this instrument was used for data collection.

\subsection{Reliability of the Instrument}

In order to ascertain the reliability of the research instrument, thirty (30) copies of the research instrument were administered on 30 students who were not part of the study. Data collected were analysed using the Cronbach Alpha statistical method. The results of the analysis showed a correlation coefficient of 0.87 . This implied that the instrument was good enough and could be used to elicit responses from the respondents.

\subsection{Method of Data Collection}

Copies of the questionnaire were administered on the respondents and after they 
were duly completed, they were retrieved by the researchers with the help of two (2) trained Research Assistants so as to achieve high instrument return rate. Out of 448 questionnaires administered, 430 were retrieved and found usable representing a $96 \%$ response rate.

\subsection{Method of Data Analysis}

Data collected were analyzed using mean and standard deviation to answer research questions 1 and 2. The decision rule was that in using the mean and the standard deviation to answer the research questions, 3.5 was used as a benchmark for high indication of each of the items of the instrument. The hypothesis was tested using the Pearson Product Moment Correlation Coefficient.

\section{Results}

\subsection{Research Question One: What Is the Level of Guidance Services Available to Students in Public Secondary Schools in the North Senatorial District of Delta State?}

Results of the data presented in Table 2 showed the mean ratings of responses by secondary school students in public schools as regards the level of guidance services available to students in public secondary schools in the North Senatorial District of Delta State. The results revealed that 6 items had the mean scores that ranged from 1.93 to 2.03 with corresponding standard deviations that ranged from 0.803 to 0.835 . However, the mean scores were indications that with respect to level of guidance services available to students in public secondary schools in the North Senatorial District of Delta State, majority of the respondents scored the school authorities low on the following items: orientation is organized for students who came into the school for the first time; students received information on how to develop interpersonal relationship; counsellors assisted students to develop effective interpersonal relationship skills; students were assisted in any way to reach self-understanding; provision of information in the selection of institution of higher learning; and new students were assisted in any way in the choice of subjects. However, only one item had a mean score of 4.47 with a corresponding standard deviation of 0.500 which was an indication that majority of the secondary school students agreed that examinations and test reports were used by counsellors to evaluate progress of students with academic problems. The corresponding standard deviations were indications of how close the responses were. The implication of this was that majority of the respondents agreed that guidance services were rarely available to students in public secondary schools in the North Senatorial District of Delta State.

\subsection{Research Question Two: What Is the Level of Students' Indiscipline in Public Secondary Schools in the North Senatorial District of Delta State?}

Results of the data presented in Table 3 showed the mean ratings of responses by secondary school students in public schools as regards the level of students' 
Table 2. Mean responses of level of guidance services available to students in public secondary schools in the north senatorial district of delta state.

\begin{tabular}{|c|c|c|c|c|c|}
\hline & Level of Guidance Services Available & $\mathrm{N}$ & $\bar{x}$ & SD & Decision \\
\hline 1 & $\begin{array}{l}\text { Orientation is organized for students who } \\
\text { came into the school for the first time. }\end{array}$ & 430 & 1.96 & 0.832 & Rarely \\
\hline 2 & $\begin{array}{l}\text { Students receive information on how to } \\
\text { develop interpersonal relationship }\end{array}$ & 430 & 2.03 & 0.803 & Rarely \\
\hline 3 & $\begin{array}{l}\text { Counsellor assists students to } \\
\text { develop effective interpersonal } \\
\text { relationship skills. }\end{array}$ & 430 & 1.98 & 0.812 & Rarely \\
\hline 4 & $\begin{array}{l}\text { Students are assisted in any way to } \\
\text { reach self-understanding. }\end{array}$ & 430 & 1.93 & 0.825 & Rarely \\
\hline 5 & $\begin{array}{l}\text { Provision of information in the selection } \\
\text { of institution of higher learning. }\end{array}$ & 430 & 1.95 & 0.835 & Rarely \\
\hline 6 & $\begin{array}{l}\text { New students are assisted in any way } \\
\text { in the choice of subjects. }\end{array}$ & 430 & 2.03 & 0.829 & Rarely \\
\hline 7 & $\begin{array}{l}\text { Exams and test reports are used by } \\
\text { counsellors to evaluate progress of } \\
\text { students with academic problems. }\end{array}$ & 430 & 4.47 & 0.500 & Rarely \\
\hline & Grand Mean & & 2.34 & & Rarely \\
\hline
\end{tabular}

KEY: Very often = VF; Often = OF; Occasionally $=$ OC; Rarely $=$ RA; Not At All = NA; Not Sure = NS.

Table 3. Mean responses of level of students' indiscipline in public secondary schools in the north senatorial district of delta state.

\begin{tabular}{|c|c|c|c|c|c|}
\hline $\mathrm{S} / \mathrm{N}$ & $\begin{array}{l}\text { Items Frequency of occurrence } \\
\text { of the following offences }\end{array}$ & $\mathrm{N}$ & $\bar{x}$ & SD & Decision \\
\hline 1 & Drinking alcohol. & 430 & 4.40 & 1.09 & Often \\
\hline 2 & Cigarette smoking. & 430 & 4.48 & 1.13 & Often \\
\hline 3 & $\begin{array}{l}\text { Taking hard drugs like cannabis sativa, } \\
\text { marijuana, heroin, etc. }\end{array}$ & 430 & 4.43 & 1.11 & Often \\
\hline 4 & Stealing. & 430 & 4.53 & 1.14 & Very often \\
\hline 5 & Bullying fellow students & 430 & 4.45 & 1.09 & Very often \\
\hline 6 & Destruction of school property. & 430 & 4.47 & 1.15 & Very often \\
\hline 7 & Noise making. & 430 & 4.50 & 1.09 & Very often \\
\hline \multirow[t]{2}{*}{8} & Sexual harassment. & 430 & 4.53 & 1.07 & Very often \\
\hline & Grand Mean & & 4.47 & & \\
\hline
\end{tabular}

KEY: Very often = VF; Often = OF; Occasionally = OC; Rarely = RA; Not At All = NA; Not Sure = NS. 
indiscipline in public secondary schools in the North Senatorial District of Delta State. The results revealed that 3 items had the mean scores that ranged from 4.40 to 4.48 with corresponding standard deviations that ranged from 1.09 to 1.13. However, the mean scores were indications that with respect to level of students' indiscipline in public secondary schools in the North Senatorial District of Delta State, majority of the respondents rated high the following as level of indiscipline in public secondary schools in North Senatorial District of Delta State: drinking alcohol, cigarette smoking and taking hard drugs like cannabis sativa, marijuana and heroin. The following 5 items had mean scores that ranged from 4.45 to 4.53 with standard deviations that ranged from 1.07 to 1.15 . The mean scores were indications that majority of the respondents rated the following level of indiscipline as very high in public secondary schools in North Senatorial District of Delta State: stealing, bullying fellow students, destruction of school property; noise making and sexual harassment. The implication of this was that majority of the respondents agreed that there were high incidences of students' indiscipline in public secondary schools in the North Senatorial District of Delta State.

\subsection{Hypothesis 1}

There is no significant relationship between the levels of guidance services and the level of students' indiscipline in public secondary schools in the North Senatorial District of Delta State.

The information in Table 4 showed that the mean score of guidance services was 2.34 with a standard deviation of 0.77 while students' indiscipline was 4.47 with a standard deviation of 1.11. The table also showed that there was a strong positive relationship (0.75) between guidance services and students' level of indiscipline. The coefficient of determination $\left(\mathrm{r}^{2}\right)$ associated with the correlation coefficient of 0.75 was 0.83 . The coefficient of determination $\left(\mathrm{r}^{2}\right)$ indicated that guidance services had influence on the students' level of indiscipline and the relationship was statistically significant at 0.00 since this significant value is lower than 0.05 the alpha level of significance. The hypothesis which stated, therefore, that there was no significant relationship between the level of guidance services and students' indiscipline in public secondary schools in the North Senatorial District of Delta State was rejected.

Table 4. Summary statistics of the Pearson correlation between the level of guidance services and levels of students' indiscipline in public secondary schools in the north senatorial district of delta state.

\begin{tabular}{ccccccc}
\hline Respondents & $\bar{x}$ & $\mathrm{SD}$ & $\mathrm{r}$ & $\mathrm{r}^{2}$ & $\mathrm{p}$-value & Decision \\
\hline $\begin{array}{c}\text { Level of Guidance } \\
\text { Services }\end{array}$ & 2.34 & 0.77 & 0.75 & 0.83 & 0.00 & Reject $\mathrm{H}_{0}$ \\
$\begin{array}{c}\text { Level of Students' } \\
\text { Indiscipline }\end{array}$ & 4.47 & 1.11 & & & & \\
\hline
\end{tabular}




\subsection{Summary of Findings}

1) Majority of the students agreed that guidance services were available to them in public secondary schools;

2) Majority of the respondents agreed that there were high incidences of indiscipline in public secondary schools in the North Senatorial District of Delta State;

3) There is significant relationship between the levels of guidance services and the levels of students' indiscipline in public secondary schools in the North Senatorial District of Delta State.

\subsection{Discussion of Findings}

The main finding of this study revealed that there was significant relationship between the level of guidance services and students' indiscipline in public secondary schools in the North Senatorial District of Delta State. This relationship may be due to the fact that guidance services usually involve provision of actionable solutions to more general, immediate issues, which involve a form of assistance which students received from teachers, parents, community members and others in their character, educational and career development. Non-availability of such services may adversely affect level of discipline among students. This may have accounted for this significant relationship. This finding is in agreement with that of Eliamani, Richard, \& Baguma (2013) who carried out a study on "Access to guidance services and its influence on students' school life and indiscipline", which revealed that accessing guidance services had an impact on students' school life as well as curbing the rates of students' indiscipline.

The result of this work also supported Onyango, Aloka, \& Raburu (2018) who carried out a study on the effectiveness of guidance and counseling in the management of student indiscipline in Public Secondary Schools in Kenya, where they established that there was a correlation coefficient of $r=0.503$ between guidance and counselling and the management of students behaviour.

\section{Educational/Counselling Implications}

From the findings, it could be deduced that:

1) Non-availability of guidance services is usually the cause of apparent lack of students' discipline especially in public secondary schools in Nigeria.

2) Guidance counsellors, especially in the public secondary schools need to improve on their reach-out level as findings showed that even where guidance services are available it is at a low level.

\section{Contribution to Knowledge/Practice}

This study contributed to knowledge as it had established the fact that, for effective level of students' discipline to be maintained in public secondary schools, guidance services must be made available in schools. 


\section{Conclusion}

It could be concluded in this study that availability of guidance services are significantly related to the students' level of indiscipline in public secondary schools in North Senatorial District of Delta State.

\section{Recommendations}

Based on the findings of this study, the following recommendations were made:

1) Principals and other school administrators in public secondary schools should put in place guidance services and provide an office where privacy would be made a priority. This would encourage more students to visit the office.

2) Guidance and counselling teachers should be well trained on how to carry out their duties by being sent to attend many seminars and workshops to improve on their skills. These skills include Focusing, Encouragers, Paraphrasing and Summarising, Questioning, Attending Behaviour, Negotiation Skills, Reflection of Meaning, Confrontation, Self-Disclosure, Noting and Reflection, Client Observation, and others. Some of these microskills are also referred to as "influencing skills". These skills are constantly applied throughout the counselling process to build rapport with clients and to work through presenting issues with them. Also to increase their professional effectiveness in understanding their clients. Because when communicating with clients, flexibility and responsiveness are two important skills a counsellor can have. Different mindsets and emotional states require a particular approach; and the counsellor's ability to adjust to a client's needs normally dictates the outcome of that relationship. Finally, attending seminars and conference will help them to be knowledgeable and flexible.

3) For adequate provision of guidance and counselling materials as well as application of peer counselling, there ought to be proper budgeting for the same in terms of finances and time respectively.

\section{Limitation of the Study}

The findings of this study were limited to public secondary schools in the North Senatorial District of Delta State. Therefore, further research is recommended to be carried out in another Senatorial District outside this District and state. Also, the study was limited to public secondary schools only; it is also recommended that same research study be carried out sampling the private secondary schools.

\section{Conflicts of Interest}

The authors declare no conflicts of interest regarding the publication of this paper.

\section{References}

Adler, P. A., \& Adler, P. (1998). Peer Power: Preadolescent Culture and Identity. London: Rutgers University Press. 
Bandura, A. (1977). Social Learning Theory. Englewood Cliff, NJ: Prentice Hall.

Bandura, A. (1995). Exercise of Personal and Collective Efficacy in Changing Societies. In A. Bandura (Ed.), Self-Efficacy in Changing Societies (pp. 1-45). New York: Cambridge University Press. https://doi.org/10.1017/CBO9780511527692

Denga, D. I. (2012). Guidance and Counselling in School and Non School Settings (2nd ed.). Port Harcourt: Double Diamond Publications.

Eliamani, M. P., Richard, L. M., \& Baguma, P. (2013). Access to Guidance and Counseling Services and Its Influence on Students' School Life and Career Choice. International School Journal, 1, 007-015.

Erford, B. T. (2011). Transforming the School Counseling Profession. Upper Saddle River, NJ: Prentice Hall.

Federal Republic of Nigeria, FRN (2004). National Policy on Education. Lagos: NERDC Press.

Franken, R. E. (2017). Human Motivation (4th ed.). Pacific Grove, CA: Brooks/Cole Publishing Co.

Franzoi, S. L. (2010). Social Psychology(2nd ed.). Boston, MA: McGraw-Hill.

Krejcie, R. V., \& Morgan, D. W. (1970). Determining Size for Research Activities. Educational and Psychological Measurement, 30, 607-610. https://doi.org/10.1177/001316447003000308

Omulema, B. E. E. (2011). Theory and Techniques of Counselling. Unpublished Manuscript, Njoro: Amu Press.

Onyango, P. A., Aloka, P. J., \& Raburu, P. (2018). Effectiveness of Guidance and Counselling in the Management of Students Behavior in Public Secondary Schools in Kenya. International Journal of Applied Psychology, 8, 6-11.

Salgong, V. K., Ngumi, O., \& Chege, K. (2016). The Role of Guidance and Counseling in Enhancing Student Discipline in Secondary Schools in Koibatek District. Journal of Education and Practice, 7, 142-151.

Wambui, A. (2015). Effectiveness of Guidance and Counselling Services in Secondary Schools in Kenya: A Case Study of Githunguri Sub-County in Kiambu County. American Journal of Educational Science, 1, 204-209. 